\title{
KEWIRAUSAHAAN SOSIAL PADA PONDOK PESANTREN SIDOGIRI PASURUAN
}

\author{
Azel Raoul Reginald \\ Mahasiswa Program Studi S-1 Ekonomi Islam - Fakultas Ekonomi dan Bisnis - Universitas \\ Airlangga \\ Email: azel_raoul@yahoo.com \\ Imron Mawardi \\ Departemen Ekonomi Syariah - Fakultas Ekonomi dan Bisnis - Universitas Airlangga \\ Email: ronmawardi@gmail.com
}

\begin{abstract}
Joblessness and lack of social welfare are economic problems which require the involvement of all people to overcome. The education aspect which functions to prepare educated human resource also plays important roles in reducing the level of joblessness and increase the social welfare. Islamic Boarding School Sidogiri Pasuruan as an educational institution not only provides Salaf education materials, but gives social benefits through its social entrepreneurship program.

The aim of this research is to discover the social entrepreneurship applied at Islamic Boarding School Sidogiri Pasurvan. This research uses qualitative descriptive approach, by using a qualitative research of case study. Technique of data collection applied in this research is through documents, interview, participatory observation, and documentation upon the informants selected by using purposive sampling methods.

The results of the research show that the application of social entrepreneurship at Islamic Boarding School Sidogiri Pasuruan can be proven by the innovation of establishment of social entrepreneurship institution, i.e. Kopontren Sidogiri (Cooperative of Islamic Boarding School Sidogiri), Pustaka Sidogiri, Buletin Sidogiri (Sidogiri Buletin), BMT Maslahah, BMT UGT Sidogiri, BPRS UMMU Sidogiri dan Koperasi Agro Sidogiri (Sidogiri Agribusiness Cooperative). They have been established based on the ideas and roles of civil society of Islamic Boarding School Sidogiri Pasuruan to maintain the economic activities, i.e. the duty of delivering Islamic values (dakwah), business, and providing social values for the society around Islamic Boarding School Sidogiri Pasuruan.
\end{abstract}

Keyword: social entrepreneurship, Islamic Boarding School Sidogiri Pasuruan.

\section{PENDAHULUAN}

\section{A. Latar belakang}

Pengangguran dan kurangnya kesejahteraan hidup adalah masalah paling rumit yang masih susah ditangani pemerintah Indonesia hingga saat ini. Keterbatasan lapangan kerja dan kurangnya minat berwirausaha merupakan akar penyebab dari semua permasalahan tersebut.

Berdasarkan berita resmi Badan Pusat Statistik Tingkat Pengangguran Terbuka (TPT) Indonesia per Februari 2013 mencapai 5,92 persen atau sebesar 7,2 juta orang dimana pendidikan menengah masih tetap menempati posisi tertinggi sehingga dapat disimpulkan bahwa Iulusan pendidikan pun masih banyak yang menganggur sehingga belum banyak yang mandiri dalam hal pemenuhan kebutuhan ekonominya.

Memasuki era kompetitif seperti sekarang, orientasi menciptakan tenaga kerja yang berkualitas harus diimbangi dengan terciptanya wirausahawan yang berkualitas dengan kuantitas yang tinggi pula sehingga semakin banyaknya wirausahawan yang berkualitas maka 
jumlah lapangan kerja dan pendapatan ekonomi masyarakat pun meningkat dan berdampak pada menurunnya jumlah pengangguran. Melihat kondisi tersebut, maka dunia pendidikan harus mampu berperan aktif menyiapkan sumber daya manusia terdidik yang mampu menghadapi berbagai tantangan kehidupan. Dunia pendidikan tidak cukup hanya menguasai teori-teori melainkan juga mau dan mampu menerapkannya dalam kehidupan sosial. Pendidikan tidak hanya mampu menerapkan ilmu yang diperoleh di bangku sekolah saja melainkan juga mampu memecahkan berbagai persoalan yang dihadapi dalam kehidupan sehari-hari. Pendidikan yang demikian adalah pendidikan yang berorientasi pada kewirausahaan yaitu jiwa keberanian dan kemavan menghadapi problema hidup dan kehidupan secara wajar, jiwa kreatif untuk mencari solusi dan mengatasi problema tersebut, jiwa mandiri dan tidak bergantung pada orang lain (Rahmat, 2011:1). Pendidikan kewirausahaan harus ditumbuhkan sebagai minat semangat membangun jiwa kewirausahaan sejak bangku pendidikan sehingga ketika lulus sekolah mereka siap membuka usaha. Kebijakan terhadap pendidikan kewirausahaan di jenjang pendidikan harus ditempuh dengan visi mencetak lulusan menjadi wirausahawan sukses.

Pemerintah Indonesia memasukkan materi kewirausahaan dalam kurikulum pendidikan nasional mulai tahun 2010 pada seluruh jenjang pendidikan, baik pendidikan umum maupun madrasah di pondok pesantren (Saputro, 2012). Adanya ilmu kewirausahaan dalam kurikulum pendidikan sangat berdampak positif pada penciptaan lapangan kerja, pertumbuhan ekonomi dan kesejahteraan masyarakat Indonesia sehingga dapat dikatakan bahwa sistem kewirausahaan yang diterapkan adalah sistem kewirausahaan sosial. Konsep wirausaha sosial atau social entrepreneur berbeda dengan konsep business entrepreneur dimana business entrepreneur meskipun mendorong terciptanya kegiatan-kegiatan ekonomi tetapi tetap saja memiliki semangat menumpuk kekayaan pada dirinya sendiri. Sedangkan wirausaha sosial atau social entrepreneur apabila memiliki kekayaan dari aktivitas ekonomi maka kekayaan tersebut digunakan untuk menolong masyarakat (Juwaini, 2011 :257).

Begitu pula dengan konsep secara umum dari kewirausahaan sosial yang juga tidak sama dengan konsep CSR (Corporate Social Responsibility) dimana perusahaan melakukan CSR dengan tujuan dengan diadakannya kegiatan tersebut maka diharapkan masyarakat lebih mengenal perusahaan tersebut. Sedangkan kewirausahaan sosial merupakan sebuah konsep kewirausahaan yang murni bergerak di bidang sosial sehingga menjadi kewajiban setiap muslim untuk melakukan hal yang baik dan mencontohkan hal baik tersebut untuk sesamanya sehingga 
tersirat bahwa merupakan kewajiban setiap muslim yang mampu untuk membantu yang lemah karena kewirausahaan sosial tidak menekankan pada usaha tujuan utama untuk menghasilkan profit melainkan inti utama dari kewirausahaan sosial ini adalah pemberdayaan umat untuk kemaslahatan bersama sebab kewirausahaan dianggap sebagai jihad fisabilillah (berjuang di jalan Allah) dan sebagai amal sholeh karena kegiatan kewirausahaan menyediakan pendapatan kepada individu serta menawarkan kesempatan kerja kepada masyarakat sehingga mengurangi kemiskinan.

Melihat dampak tersebut, kini ada pondok pesantren di Jawa Timur yang merupakan salah satu pondok pesantren mandiri dari aspek perekonomiannya. Pondok pesantren tersebut telah memiliki pengembangan dan pemberdayaan perekonomian mandiri sehingga di samping sebagai lembaga pendidikan, pondok pesantren tersebut memiliki peranan yang besar dalam hal kemandirian internal pondok pesantren dan juga untuk memberdayakan perekonomian masyarakat, khususnya bagi masyarakat ekonomi menengah ke bawah yang berdomisili di sekitar pondok pesantren melalui kegiatan eksternalnya. Pondok pesantren mandiri yang dimaksud adalah Pondok Pesantren Sidogiri Pasuruan Jawa Timur yang merupakan pondok pesantren Salaf yang kini juga berkembang dalam hal perekonomian sehingga menyebabkan pondok pesantren tersebut bisa mandiri di segala aspeknya. Bahkan, menurut Mawardi dan Nafik (2011:3) saat ini lembaga bisnis Pondok Pesantren Sidogiri Pasuruan telah menjadi kekuatan ekonomi santri yang sangat besar dan telah didesain tergabung dalam forum jaringan Sidogiri.

Berdasar uraian tersebut, maka penulis tertarik untuk melakukan penelitian pada Pondok Pesantren Sidogiri Pasuruan Jawa Timur dengan judul "kewirausahaan sosial pada Pondok Pesantren Sidogiri Pasuruan". Penelitian dilakukan pada Pondok Pesantren Sidogiri Pasurvan karena pondok pesantren tersebut merupakan salah satu pondok pesantren yang memiliki lembaga-lembaga kewirausahaan sosial yang cukup mapan dan mampu berperan aktif dalam hal pemberdayaan masyarakat sekitarnya sehingga penelitian ini memiliki peran yang cukup penting bagi perkembangan kewirausahaan Islam ke depan, baik kewirausahaan Islam yang sudah maupun belum berkembang. Penulis tertarik melakukan penelitian yang berkaitan dengan hal tersebut karena nantinya hasil penelitian ini diharapkan dapat diaplikasikan pada kewirausahaaan Islam yang lain dengan harapan mau meniru sistem kewirausahaan sosial yang telah diterapkan oleh Pondok Pesantren Sidogiri Pasuruan ini.

Berdasarkan latar belakang dan melihat fenomena kasus yang terjadi, maka 
rumusan masalah dalam penelitian ini adalah bagaimana penerapan kewirausahaan sosial pada Pondok Pesantren Sldogiri Pasuruan? Adapun tujuan penelitian ini adalah untuk mengetahui penerapan kewirausahaan sosial pada Pondok Pesantren Sidogiri Pasuruan.

\section{LANDASAN TEORI \\ PENGEMBANGAN HIPOTESIS}

DAN

\section{A. Kewirausahaan}

Priyanto (2009:61-62) menyatakan bahwa kewirausahaan merupakan sesuatu yang ada di dalam jiwa seseorang, masyarakat dan organisasi yang karenanya akan dihasilkan berbagai macam aktivitas (sosial, politik, pendidikan), usaha dan bisnis. Kewirausahaan merupakan bidang yang sangat luas aktivitasnya, mulai dari individual entrepreneurship, industrial entrepreneurship sampai yang terakhir berkembang adalah social entrepreneurship.

Kewirausahaan dalam Islam

Departemen Agama Republik Indonesia (2009) menyebutkan bahwa konteks kewirausahaan dalam Islam tertera pada Al-Qur'an Surat An-Nisa (4) ayat 29 yang berbunyi:

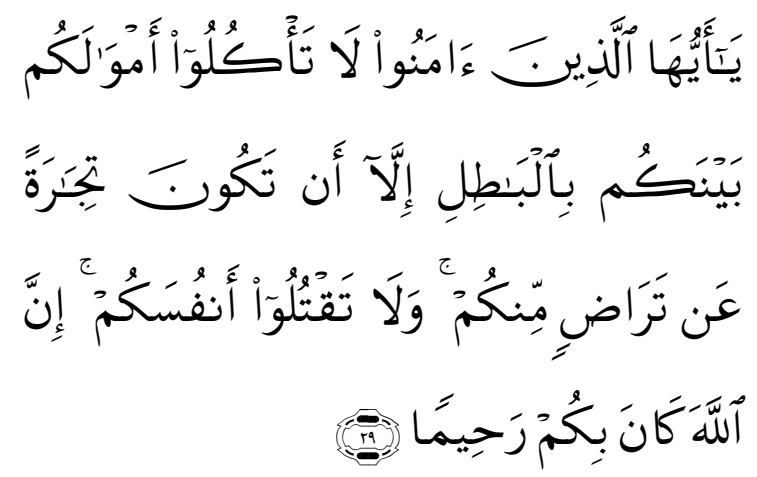

Artinya: "Hai orang-orang yang beriman, janganlah kamu saling memakan harta sesamamu dengan jalan yang batil, kecuali dengan jalan perniagaan yang berlaku dengan suka sama-suka di antara kamu, dan janganlah kamu membunuh dirimu, sesungguhnya Allah adalah Maha Penyayang kepadamu."

\section{B. Kewirausahaan Sosial}

Kewirausahaan sosial adalah suatu proses yang melibatkan penggunaan dan penggabungan sumber daya secara inovatif untuk membuka peluang mempercepat perubahan sosial dan/atau memenuhi kebutuhan sosial (Mair dan Marti, 2006 dalam Sakai dan Marijan, 2008:3) sehingga dapat disimpulkan bahwa kewirausahaan sosial bertujuan untuk menyelesaikan permasalahan sosial di masyarakat dan bukan semata - mata untuk mencari keuntungan saja yang mana karakteristik kewirausahaan sosial di antaranya yakni pencipataan social value, innovation, civil society, dan adanya economic activity (Hulgard, 2010).

\section{Kewirausahaan Sosial dalam Islam}

Islam mengajarkan bahwa membantu orang lain melalui kewirausahaan sosial ditekankan di banyak ayat dalam AlQur'an sebagaimana yang telah disebutkan dalam firman Allah SWT yang berbunyi:

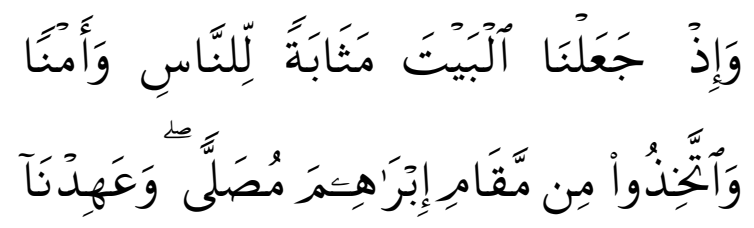




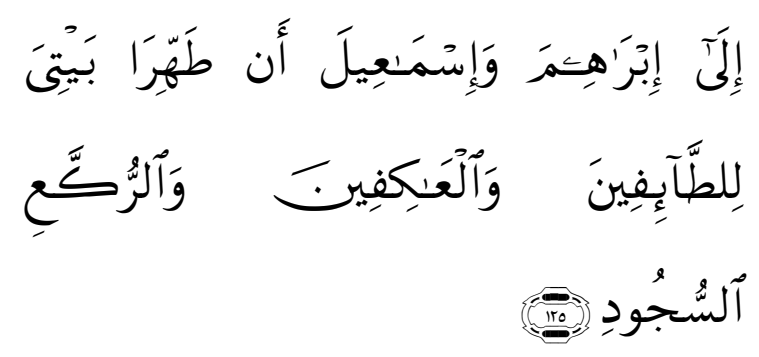

Artinya: "Dan belanjakanlah (harta bendamu) di jalan Allah, dan janganlah kamu menjatuhkan dirimu sendiri ke dalam kebinasaan, dan berbuat baiklah, karena sesungguhnya Allah menyukai orang-orang yang berbuat baik." (QS. Al-Baqarah [2]:195:Departemen Agama Republik Indonesia, 2009)

Konsep kewirausahaan sosial juga telah tertera dalam HR. Muslim (no. 1017), Tirmidzi (no. 2675) dan An Nasa-i (no. 2554) yang berbunyi:

نف يس يةً عش نر"جأ يه صقني نأ ريغ يه هدعب ايب لوع يه رجاً

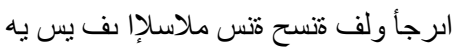

عش نرا "أ يه صقني بأ ريغ يه هدعب يه ايب لوع يه رًَ ابر "

ويلع لا ة يس متس ملاسلإِ

Artinya: "Barangsiapa yang mencontohkan sunnah yang baik di dalam Islam maka baginya pahala dan pahala orang yang mengerjakan sunnah tersebut setelahnya tanpa mengurangi dari pahala-pahala mereka dan barangsiapa yang mencontohkan sunnah yang buruk di dalam Islam maka baginya dosa dan dosa yang mengerjakan sunnah yang buruk tersebut setelahnya tanpa mengurangi dosa-dosa sedikitpun pelakunya."

\section{Pondok Pesantren}

Qomar (2005:109, dalam Vadlan, 2008:19) mengatakan bahwa pondok pesantren adalah suatu tempat yang tersedia untuk santri dalam menerima pelajaran- pelajaran agama Islam sekaligus tempat berkumpul dan tempat tinggalnya. Pondok pesantren dibagi menjadi dua jenis yaitu pondok pesantren Salaf dan pondok pesantren Khalaf yang mana menurut Walsh (2002:18) pondok pesantren Salaf yaitu sistem yang tetap mempertahankan pengajaran kitab-kitab Islam klasik sebagai inti pendidikan di pondok pesantren sedangkan pondok pesantren Khalaf merupakan sistem pendidikan yang berusaha mengintegrasikan secara penuh sistem pendidikan tradisional dengan sistem pendidikan formal. Sriharini (2003:42) menyebutkan bahwa unsurunsur pondok pesantren di antaranya adalah pondok (asrama atau tempat tinggal santri sementara dan juga sebagai tempat mengulang pelajaran yang telah diajarkan oleh kyai dan ustad), pesantren (madrasah atau sekolah santri), kyai dan ustadz (pemegang kendali manajerial pesantren dan juga sebagai pendidik atau pengajar), santri (peserta didik di pesantren), masjid (sebagai tempat beribadah sholat dan pengajian), sistem tata nilai (salaf atau khalaf) serta pengajaran kitab-kitab klasik / kitab kuning. 


\section{Metode Penelitian}

\section{A. Pendekatan Penelitian}

Pendekatan yang digunakan dalam penelitian ini adalah kualitatif deskriptif dengan menggunakan strategi penelitian studi kasus.

\section{B. Ruang Lingkup Penelitian}

Ruang lingkup penelitian pada penelitian ini hanya meneliti tujuh orang informan yang terdiri dari dua orang pengurus Pondok Pesantren Sidogiri Pasuruan, satu orang santri Aliyah jurusan Muamalah dan empat orang alumni santri Pondok Pesantren Sidogiri Pasuruan serta terbatas pada bentuk kewirausahaan sosial pada Pondok Pesantren Sidogiri Pasuruan saja.

\section{Jenis dan Sumber Data}

Herdiansyah (2010:116) mengatakan bahwa data dalam penelitian kualitatif dibagi menjadi dua yaitu data primer yang berupa data yang berasal dari hasil wawancara dan observasi dari lapangan sehingga datanya lebih banyak berwujud kata-kata dan tindakan dari objek penelitian serta data sekunder berupa data yang sudah ada yang berkaitan dengan penelitian seperti dokumen.

Dalam penelitian ini, data primer berasal dari wawancara dan observasi partisipatif pada informan penelitian seperti pengurus, santri dan alumni santri sebagai pihak yang ikut berkecimpung dalam kewirausahaan sosial pada Pondok Pesantren Sidogiri Pasuruan. Sedangkan data sekunder dalam penelitian ini berasal dari data penunjang berupa dokumen-dokumen administratif yang berkaitan dengan penelitian yang diperoleh dari Pondok Pesantren Sidogiri Pasuruan dan berasal dari studi dokumentasi yang didapatkan dari buku-buku, jurnal, internet, makalah, dan literatur atau kajian pustaka yang relevan atau berkaitan dengan permasalahan kewirausahaan sosial.

Selain itu, penelitian ini juga menggunakan teknik purposive sampling yang merupakan teknik mendapatkan informan dengan menentukan subjek / objek menggunakan pertimbangan pribadi informan tersebut dianggap mengetahui dan paham secara keseluruhan mengenai kewirausahaan sosial pada Pondok Pesantren Sidogiri Pasuruan. Prosedur Pengumpulan Data Dalam penelitian kualitatif pengumpulan data dapat dilakukan dengan menggunakan beberapa cara yaitu dari dokumen, rekaman arsip, wawancara, observasi langsung, observasi partisipatif, dan perangkat fisik (Yin, 2012:103) namun dalam penelitian ini peneliti hanya melakukan wawancara dan observasi partisipatif pada pengurus, santri maupun alumni santri terkait kewirausahaan sosial pada Pondok Pesantren Sidogiri Pasuruan, menggunakan perangkat fisik berupa dokumentasi penelitian serta menggunakan dokumen berupa dokumen-dokumen administratif yang berkaitan dengan penelitian seperti dokumen yang ditulis oleh Naji, dkk 
berupa Tamassya (Laporan Tahunan Pengurus Pondok Pesantren Sidogiri Pasuruan) dan dokumen tentang kewirausahaan sosial Pondok Pesantren Sidogiri Pasuruan.

\section{Teknik Analisis}

Yin (2012:133) berpendapat tentang tiga macam bentuk teknik analisis yang sering digunakan antara lain penjodohan pola, pembuatan penjelasan (deskriptif), dan analisis deret waktu. Teknik analisis yang digunakan dalam penelitian ini adalah teknik analisis deskriptif atau dapat disebut pembuatan penjelasan yaitu dengan menggunakan metode analisis data dan mendeskripsikan hasil observasi wawancara, serta bertujuan untuk mengetahui secara mendalam mengenai kewirausahaan sosial pada Pondok Pesantren Sidogiri Pasuruan.

\section{HASIL PENELITIAN DAN PEMBAHASAN}

Berdasarkan hasil wawancara serta hasil observasi partisipatif pada penelitian mengenai kewirausahaan sosial menunjukkan bahwa Pondok Pesantren Sidogiri Pasuruan telah menerapkan kewirausaan sosial yaitu dengan melihat pada elemen utama dalam kewirausahaan sosial menurut Hulgard (2010) yaitu innovation, economic activity, social value dan civil society. Dalam hal innovation, Pondok Pesantren Sidogiri Pasuruan memecahkan masalah sosial dengan cara-cara inovatif yang memadukan kearifan lokal dan inovasi sosial yaitu dengan membangun kewirausahaan sosial berupa berdirinya Kopontren Sidogiri, BMT Maslahah, BMT UGT, BPRS UMMU, Koperasi Agro, Pustaka Sidogiri dan Buletin Sidogiri namun seperti yang diutarakan teori Qozazirin, dkk (2008:3-4) mengenai karakteristik kewirausahaan sosial yang kedua yaitu pengambilan keputusan pada lembagalembaga wirausaha sosial ini tidak didasari oleh kepemilikan modal melainkan keputusan dikeluarkan oleh masing-masing pengurus lembagalembaga wirausaha sosial tersebut seperti pada konsep koperasi yaitu kedudukan tertinggi ada pada pengurus termasuk dalam hal penyaluran dana sosial. Dana sosial tersebut dimasukkan dalam rencana kerjanya tetapi anggota pun juga tahu informasi-informasi rencana kerjanya tersebut sehingga apa yang menjadi rencana kerja pengurus koperasi harus disepakati oleh anggotanya.

Kopontren Sidogiri pada tahun 1382 $H$ atau 1961 M yang mengedepankan konsep lembaga bisnis dari santri, oleh santri dan untuk santri serta mendirikan lembaga berkonsep setengah bisnis setengah sosial berupa Buletin Sidogiri pada tahun $1426 \mathrm{H}$ atau $2005 \mathrm{M}$ yang diciptakan sebagai media dakwah yang menjual buletin tetapi bukan semata-mata untuk profit melainkan hanya sebatas dakwah saja dan Pustaka Sidogiri yang didirikan pada tahun 1427 H 2006 M sebagai media dakwah yang menjual buku-buku terbitan Pondok Pesantren Sidogiri Pasuruan. Kemudian dalam hal economic activity dari 
kewirausahaan sosial tersebut adalah dengan adanya Kopontren Sidogiri, Pustaka Sidogiri, dan Buletin Sidogiri itu sangat membantu program dakwah ekonomi Pondok Pesantren Sidogiri Pasuruan dengan menyeimbangkan motto khairunnas anfa'uhum linnas dan rabbana atina fidunya hasanah wafil akhirati hasanah waqina adzabannar. Dengan didirikannya lembaga wirausaha sosial seperti Kopontren Sidogiri sebagai wadah berkhidmah dan pemberdayaan santri maka diharapkan santri juga memperoleh keuntungan baik dari segi ilmu pendidikan, pengalaman wirausaha dengan berakhlaqul-karimah, menumbuhkan jiwa, minat dan bakat wirausaha sosial santri, serta juga keuntungan finansial dalam bentuk bisyaroh maupun beasiswa pendidikan sehingga secara tidak langsung bagi santri yang berkhidmah seperti di Kopontren Sidogiri itu bisa mandiri secara ekonomi dan lebih sejahtera di samping guna menjaga kemandirian prinsip Salaf dan ekonomi Pondok Pesantren Sidogiri Pasurvan. Pondok Pesantren Sidogiri Pasurvan berbisnis (bermuamalah) itu hanyalah semata-mata dilakukan di dunia untuk menopang orientasi kehidupan di akhirat guna mengingat pola dan misi yang dijalankan Rasulullah SAW dalam menciptakan masyarakat madani yang tidak bisa lepas dari menciptakan atau membuka peluang pasar di luar masjid. Tujuan utama Pondok Pesantren Sidogiri Pasuruan adalah tafaqquh fiddin yang salah satu caranya dengan membangun pondasi pendidikan Salaf-nya. Sedangkan bisnisbisnis Pondok Pesantren Sidogiri Pasuruan hanyalah sebagai salah satu hasil dari bangun pondasi pendidikan Salaf tersebut.

Innovation lain terkait kewirausahaan sosial pada Pondok Pesantren Sidogiri Pasurvan ada dalam bentuk program eksternal Pondok Pesantren Sidogiri Pasurvan dan lebih mengarah pada program kewirausahaan sosial IASS (Ikatan Alumni Santri Sidogiri) yaitu dalam hal menjauhkan masyarakat sekitar Pondok Pesantren Sidogiri Pasuruan dari dampak negatif praktek ribawi yang dilakukan oleh rentenir sehingga pada tahun 1997 didirikanlah BMT MMU Sidogiri (brand awal BMT Maslahah). Setelah berhasilnya program BMT MMU Sidogiri (brand awal BMT Maslahah) kemudian beberapa tahun setelah itu berdirilah lembaga-lembaga wirausaha sosial Sidogiri lainnya seperti BMT UGT Sidogiri, BPRS UMMU Sidogiri, dan Koperasi Agro Sidogiri yang sama-sama merupakan bisnis berbasis syariah.

Lembaga-lembaga wirausaha sosial tersebut berasal dari inisiatif dan partisipasi masyarakat sipil (civil society) yang dalam hal ini menyangkut internal Pondok Pesantren Sidogiri Pasuruan, alumni santri dan komunitasnya dengan mengoptimalkan modal sosial yang ada di masyarakat atau dihubungkan dengan teori Qozazirin, dkk (2008:3-4) mengenai karakteristik kewirausahaan sosial yang pertama yaitu kegiatan dirintis oleh 
sekelompok warga / komunitas dan yang ketiga yaitu sifatnya partisipatif, terutama melibatkan mereka yang dipengaruhi oleh kegiatan dan dampak kewirausahaan sosial tersebut. Dalam hal ini civil society atau sifat partisipatif sekelompok masyarakat yang merintis dan yang memperoleh dampak kegitan kewirausahaan sosial dapat dibuktikan berupa pembentukan lembaga wirausaha sosial Pondok Pesantren Sidogiri Pasuruan yang muncul dari ide dan komunikasi intens pengurus internal dan eksternal Pondok Pesantren Sidogiri Pasurvan dengan niat menjalankan usaha sesuai syariah dengan pedoman khairunnas anfa'uhum linnas terkait program dakwah ekonomi dengan tujuan sosial untuk mengedukasi praktek syariah pada masyarakat, ta'awun (tolong menolong) dalam bentuk zakat dan dana sosial, pemberdayaan baik pemberdayaan santri, alumni santri, maupun masyarakat sekitar, membantu keuangan Pondok Pesantren Sidogiri Pasuruan serta guna mempermudah pemenuhan kebutuhan santri. Selain itu, kolaborasi komunitas SNF yaitu perpaduan antara internal Pondok Pesantren Sidogiri Pasuruan dengan alumni santrinya dengan motto khidmatan lil ma'at wa khidmatan lil ummat memiliki misi ingin memberikan kontribusi lewat civil society bagaimana mewujudkan baldatun thoyyibbatun wa rabbun ghafur dengan membangun qoryah thoyyibbah yang sasarannya yaitu pendidikan, ekonomi dan sosial sehingga diharapkan bisa membantu menurunkan angka kemiskinan dan pengangguran. Hal tersebut sangat sesuai dengan pemahaman kewirausahaan sosial yang ada pada HR. Muslim (no. 1017), Tirmi dzi (no. 2675) dan An Nasa-i (no. 2554) berikut ini yang berbunyi:

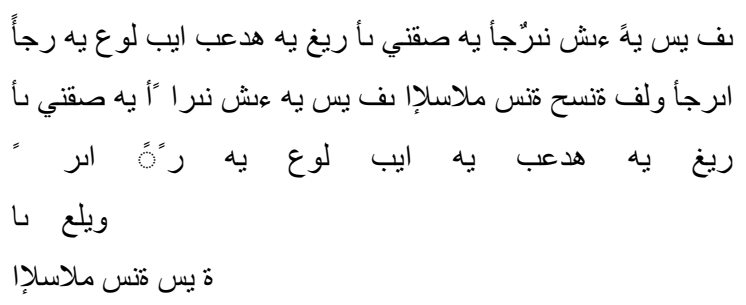

Artinya: "Barangsiapa yang mencontohkan sunnah yang baik di dalam Islam maka baginya pahala dan pahala orang yang mengerjakan sunnah tersebut setelahnya tanpa mengurangi dari pahala-pahala mereka dan barangsiapa yang mencontohkan sunnah yang buruk di dalam Islam maka baginya dosa dan dosa yang mengerjakan sunnah yang buruk tersebut setelahnya tanpa mengurangi dosa-dosa sedikitpun pelakunya."

dan juga sesuai dengan kewirausahaan sosial yang tertera pada surat Al-Baqarah (2) ayat 195:
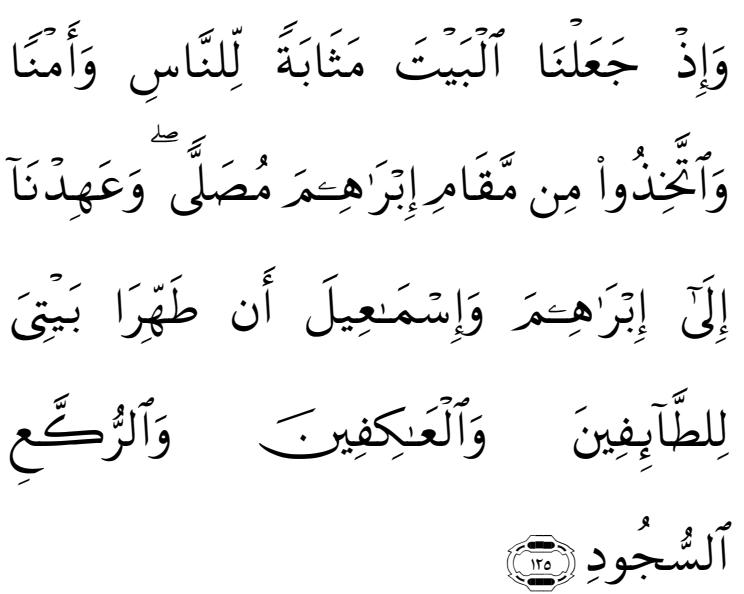
Artinya: "Dan belanjakanlah (harta bendamu) di jalan Allah, dan janganlah kamu menjatuhkan dirimu sendiri ke dalam kebinasaan, dan berbuat baiklah, karena sesungguhnya Allah menyukai orang-orang yang berbuat baik."

Berdasarkan hasil wawancara mengenai kewirausahaan sosial serta hasil observasi partisipatif pada penelitian menunjukkan bahwa Pondok Pesantren Sidogiri Pasuruan telah menerapkan kewirausahaan sosial yang juga dengan memberikan social value yaitu menciptakan manfaat sosial yang nyata bagi masyarakat dan lingkungan sekitar atau digabungkan pada teori Qozazirin, dkk (2008:3-4) mengenai karakteristik kewirausahaan sosial yang kelima yaitu tujuan sosial / manfaat komunitas dinyatakan secara eksplisit. Social value atau tujuan sosial kewirausahaan sosial Pondok Pesantren Sidogiri Pasuruan bisa dibuktikan dengan adanya pendidikan kewirausahaan sosial yang diajarkan secara implisit pada pendidikan Salaf dengan dengan dihubungkan pada praktek (aplikasi sistem) di lembaga wirausaha sosial Pondok Pesantren Sidogiri Pasuruan sehingga santri mendapatkan pendalaman atau pelengkap ilmu wirausaha sosial dan juga pengalaman bekerja namun tetap dalam koridor tafaqquh fiddin. Dengan adanya lembaga wirausaha sosial seperti Kopontren Sidogiri maka santri dan masyarakat sekitar Pondok Pesantren Sidogiri Pasuruan lebih mudah dalam hal pemenuhan kebutuhan hidupnya sehari- hari. Sedangkan dengan adanya Buletin Sidogiri dan Pustaka Sidogiri sebagai lembaga wirausaha sosial dalam bentuk media dakwah maka santri dan masyarakat bisa lebih mudah menerima dakwah yang ada dalam buku maupun buletin terbitan Pondok Pesantren Sidogiri Pasuruan. Selain itu, dengan adanya ketiga lembaga wirausaha sosial tersebut dapat menjadi penyokong dana operasional Pondok Pesantren Sidogiri Pasuruan yang berdampak pada keberhasilan Pondok Pesantren Sidogiri Pasuruan dalam hal menjaga prinsip kemandiriannya baik kemandirian Salaf maupun kemandirian secara ekonomi.

Kewirausahaan sosial Pondok Pesantren Sidogiri Pasuruan juga dapat diidentifikasi dengan menghubungkan hasil wawancara dengan teori Qozazirin, dkk (2008:3-4) mengenai karakteristik kewirausahaan sosial yang keempat yaitu pembagian keuntungan yang terbatas dengan bukti lembaga wirausaha sosial Pondok Pesantren Sidogiri Pasuruan memperoleh keuntungan yang mana keuntungan tersebut dibagikan terbatas atau lebih digunakan untuk menyokong dana operasional Pondok Pesantren Sidogiri Pasuruan, untuk bisyaroh dan beasiswa pendidikan santri terutama santri yang berkhidmah di lembaga wirausaha sosial Pondok Pesantren Sidogiri Pasuruan, untuk digunakan sebagai dana zakat dan dana sosial sehingga memberikan manfaat bagi masyarakat 
sekitar Pondok Pesantren Sidogiri Pasuruan.

\section{KESIMPULAN DAN SARAN}

\section{A. Simpulan}

Berdasarkan hasil analisis dan pembahasan penelitian maka dapat diperoleh simpulan bahwa Pondok Pesantren Sidogiri Pasuruan menerapkan kewirausahaan sosial yaitu dengan innovation pembentukan lembaga wirausaha sosial milik internal seperti Kopontren Sidogiri, Pustaka Sidogiri dan Buletin Sidogiri maupun lembaga milik eksternal seperti BMT Maslahah, BMT UGT Sidogiri, BPRS UMMU Sidogiri dan Koperasi Agro Sidogiri yang didirikan oleh civil society Pondok Pesantren Sidogiri Pasuruan dengan motto khidmatan lil ma'at wa khidmatan lil ummat melalui misi ingin memberikan kontribusi dalam hal mewujudkan baldatun thoyyibbatun wa rabbun ghafur dengan membangun qoryah thoyyibbah yang sasarannya yaitu pendidikan, ekonomi dan sosial sehingga diharapkan bisa membantu menurunkan angka kemiskinan dan pengangguran yang mana hal tersebut sangat sesuai dengan ada pada HR. Muslim (no. 1017), Tirmidzi (no. 2675) dan An Nasa-i (no. 2554) tentang mencontohkan sunnah yang baik di dalam Islam agar memperoleh pahala bagi orang yang mengerjakan maupun bagi orang yang mencontohkan sunnah yang baik tersebut serta sesuai dengan surat Al-Baqarah (2) ayat 195 yang intinya diwajibkan untuk membelanjakan harta dan berbuat baik dijalan Allah.dengan economic activity yang sangat membantu program dakwah ekonomi Pondok Pesantren Sidogiri Pasuruan dengan menyeimbangkan motto khairunnas anfa'uhum linnas dan rabbana atina fidunya hasanah wafil akhirati hasanah waqina adzabannar guna memberikan social value seperti kemudahan pemenuhan kebutuhan pokok internal dan eksternal Pondok Pesantren Sidogiri Pasuruan, kemudahan pembiayaan berbasis syariah, pelatihan, konsultasi dan pemberdayaan masyarakat sekitar dalam hal wirausaha.

Selain itu, social value kewirausahaan sosial pada Pondok Pesantren Sidogiri Pasuruan yaitu dalam hal ta'awun (tolong menolong) seperti pemberian zakat, infaq, sodaqoh, wakaf, beasiswa santri, bisyaroh dan asuransi kesehatan serta bagi hasil SHU (sisa hasil usaha) yang sebagiannya untuk dana sosial sebagai pemasukan atau penyokong biaya operasional Pondok Pesantren Sidogiri Pasuruan dalam hal menjalankan program dakwah dan tafaqquh fiddinnya. Kemudian Pondok Pesantren Sidogiri Pasuruan juga memberikan manfaat pada santri dalam hal pendidikan kewirausahaan sosial yang diberikan secara implisit pada beberapa mata pelajaran dan kemudian juga bisa dipraktekkan pada lembaga wirausaha sosial civitas Pondok Pesantren Sidogiri Pasuruan dengan tujuan untuk 
menyelaraskan konsep teori dengan aplikasi sistem sebagai bagian dari pendalaman atau pelengkap ilmu kewirausahaan sosial dan juga bisa berlanjut berwirausaha di luar maupun di lembaga wirausaha sosial tersebut karena sudah berpengalaman.

\section{B. Saran}

Berdasarkan hasil penelitian maka saran yang dapat diberikan dalam penelitian ini adalah sebagai berikut:

1. Bagi masyarakat maupun calon santri Pondok Pesantren Sidogiri Pasuruan, dari hasil penelitian ini seharusnya mereka lebih melihat Pondok Pesantren Sidogiri Pasuruan ini dari proses pembentukan pondasi pendidikan Salaf-nya saja dan jangan dilihat dari kewirausahaan sosialnya saja karena kewirausahaan sosial tersebut merupakan hasil dari terbentuknya pondasi pendidikan Salaf dan terbentuk dari keinginan civitas Pondok Pesantren Sidogiri Pasurvan dalam hal kemandirian prinsip, baik mandiri secara prinsip pendidikan Salaf maupun mandiri secara ekonomi.

2. Bagi penelitian selanjutnya, diharapkan penelitian ini dapat digunakan sebagai acuan atau bahan referensi bagi penelitian selanjutnya, khususnya dalam hal kewirausahaan sosial. Di samping itu, disarankan agar penelitian selanjutnya dapat memperluas informasi kewirausahaan sosial yang mungkin juga telah diterapkan pada pondok pesantren modern.

\section{DAFTAR PUSTAKA}

Badan Pusat Statistik. 2013. Keadaan Ketenagakerjaan Februari 2013. Berita Resmi Statistik No. 35/05/Th. XVI, 6 Mei 2013.

Departemen Agama Republik Indonesia. 2009. Al-Qur'an dan Terjemahannya. Jakarta: PT. Sigma Examedia Arkanleena.

Hadits Riwayat Muslim, Tirmidzi dan AnNasa'i serta terjemahannya.

Herdiansyah, Haris. 2010. Metodologi Penelitian Kualitatif untuk IImuIImu Sosial. Jakarta: Salemba Humanika.

Hulgard, Lars. 2010. Discourses of Social Entrepreneurship-Variation of The Same Theme? EMES European Research Network.

Juwaini, Ahmad. 2011. Social Enterprise Transformasi Dompet Dhuafa menjadi World Class Organization. Jakarta Selatan: Expose (Mizan Group).

Mair, Johanna dan Ignasi Marti. 2006. Definisi Kewirausahaan Sosial. Dalam Minako Sakai dan Kacung Marijan (Ed.), Mendayagunakan Pembiayaan Mikro Islami (hlm. 3). Australia: Crawford School of Economics and Government, Australian National University. 
Mawardi, Imron dan Muhammad Nafik HR.

2011. Business Network of Pesantren and Its Mashlahah (Case Study in PP Sidogiri Pasuruan East Java). Universitas Airlangga: Departemen Ekonomi Syariah.

Naji, A. Saifulloh, dkk. 2012. "Pesantren Harus Mandiri". Tamassya (Laporan Tahunan Pengurus Pondok Pesantren Sidogiri) 14321433H. Edisi 10. Pasuruan: Sekretariat Pondok Pesantren Sidogiri. . 2013. "Babak Baru Pendidikan Usia Dini". Tamassya (Laporan Tahunan Pengurus Pondok Pesantren Sidogiri) 1433-1443H. Edisi 11. Pasuruan: Sekretariat Pondok Pesantren Sidogiri.

Priyanto, Sony Heru. 2009. "Mengembangkan Pendidikan Kewirausahaan di Masyarakat". Andragogia-Jurnal PNFI, 1 (1): 5782.

Qomar, Mujamil. 2005. Pengertian Pondok Pesantren. Dalam Basori Vadlan (Ed.), Hubungan antara Kelekatan Santri pada Ustadz dengan Motivasi Belajar Santri di Pondok Pesantren Assalafiyah Mlangi Nogotirto Gamping Sleman Yogyakarta. Skripsi tidak diterbitkan (hlm.19). Yogyakarta: Fakultas Tarbiyah UIN Sunan Kalijaga.

Qozazirin, Azhar, dkk. 2008. Buku Panduan Guru: Kewirausahaan
Sosial Berbasis Sekolah. Indonesia: British Council.

Rahmat, Abdul. 2011. "Pendidikan Berwawasan Kewirausahaan pada Usia Dini". Jurnal Pedagogika, Vol. 2 No. 1 Hal: 1. Universitas Negeri Gorontalo: Jurusan Pendidikan Luar Sekolah.

Sakai, Minako dan Kacung Marijan (2008), Mendayagunakan Pembiayaan Mikro Islami.

Australia: Crawford School of Economics and Government, Australian National University.

Saputro, Maryono Nanang. 2012. Daftar HIPSI, (Online), (http://pesantrenmandiri.com/?p age_id=1492, diakses tanggal 27 September 2012).

Sriharini. 2003. Pondok Pesantren dan Pemberdayaan Ekonomi Masyarakat. Yogyakarta: Jurnal PMI Media Pemikiran Pengembangan Masyarakat.

Walsh, Mayra. 2001. Pondok Pesantren dan Ajaran Golongan Islam Ekstrim (Studi Kasus di Pondok Pesantren Modern Putri "Danur Ridwan" Parangharjo Banyuwangi). Malang: Studi Lapangan AClClS Program Fakultas IImu Sosial dan Politik Universitas Muhammadiyah Malang.

Yin, Robert K. 2012. Studi Kasus: Desain dan Metode. Edisi 1 Cetakan ke11. Jakarta: Rajawali Pers. 